\title{
Safety-oriented practices of adult bicycle riders in Brooklyn, New York USA: an interview study
}

\author{
Mark W. Hoglund ${ }^{1}$
}

\begin{abstract}
${ }^{1}$ School of Public Health, State University of New York - Downstate Health Sciences University, Brooklyn, New York USA
\end{abstract}

Email: $\quad$ mark.hoglund@downstate.edu

Orcid ID: $\quad$ 0000-0001-8792-4182

\begin{abstract}
Objective: The primary purpose of this investigation was to identify safety-oriented bicycling practices commonly used by adult riders in an urban setting (Brooklyn, New York), and to explore whether there are any differences between the safety-oriented practices of men and women riders. Methods: 24 adult riders (14 men, 10 women) in Brooklyn were interviewed concerning their perceptions of bicycling hazards and their safety-oriented practices. Interviews were recorded, transcribed, and analyzed through thematic analysis. Fisher's Exact Test was employed to test for gender differences. Results: Participants identified a variety of hazards, mainly due to motor vehicles but also pedestrians and roadway conditions. The analysis distilled twentyone bicycling practices to summarize prevalent views of the participants about safe riding practices. Related items were grouped under broader categories, generating seven safety-oriented bicycling strategies. Few differences based on gender were found in the analysis; however, women in this study were more likely than men to say that they felt disrespected by other road users. Conclusion: Seven strategies may be important for safe urban bicycling: minimizing exposure to other road users (especially motor vehicles) while riding, being vigilant and anticipating what others might do, riding in a predictable fashion, making one's presence known to other road users, making sure it is safe before proceeding, obeying traffic rules, and riding at a safe speed. Future studies could develop these concepts further and test whether they are associated with involvement in traffic crashes.
\end{abstract}

Keywords: Bicycle; Bicyclist; Behavior; Safety; Crash Prevention 


\section{Introduction}

From the perspective of public health and safety, identifying bicycling behaviors that increase or decrease crash risk is an important objective. A number of recent studies dealing with bicycling behaviors have focused on risky behavior [1-11], and several of these studies reported associations between engaging in risky behaviors and previous crashes or near-misses [1, 2, 4, 5, 7-11].

Apparently, however, only a handful of recent studies have given attention to positive bicycling behaviors $[6,8,12-14]$, and only three of them analyzed their association with crash risk $[8,12,14]$. One study [12] utilized an eight-item index to represent "bicycle safety behaviours", including six desirable practices: helmet use, using bike lights in darkness, signaling when turning, walking the bike across the street at designated crossings, making eye contact with drivers, and assuming that drivers don't see you when you pass them. Higher scores on this safety behaviors index were associated with lower crash involvement in the previous three years. Another study [8] tested 11-13 year old riders on some "higherorder cycling skills", comprising hazard perception, blind spot recognition, gap acceptance, and knowledge of priority (right-of-way) protocols. No association was found between these skills and either bicycling experience or crash history.

The third study, focusing on U.S. bicycle riders, analyzed published reports on traffic accidents and their causes to postulate six on-road "safety-oriented bicycling practices": speed, vigilance, position in traffic, yielding the right-of-way, obeying traffic laws, and checking before changing speed or direction [14]. Principal component analysis led to identification of three general safety-oriented behaviors: vigilance, cautiousness, and predictability. The study did not find evidence that vigilance or cautiousness reduced odds of crashes, but the results suggested a possible protective effect related to predictability.

It is possible that men and women have different views about what it means to ride safely. Previous studies have found women to be more cautious than men [15, 16], and women may have greater concerns than men about bicycling in traffic, motorist aggression, 
inclement weather, cycling skills, and the capability to deal with bicycle maintenance issues on the road [17]. Women have self-reported higher levels of "positive cycling behaviors" and perception of cycling risk, but they also reported higher levels of psychological distress [6]. Although men have self-reported higher levels of risky cycling behaviors than women, men have also demonstrated more knowledge of traffic norms [6], and they scored higher on a measure of cycling competence [16]. Based on observations of bicyclists, men were deemed less likely than women to experience conflicts with motor vehicles at intersections [18].

Results of an observation study [19] suggested that women would rather ride on offroad paths than on roads, whether or not the roads had bicycle lanes. Although both men and women may prefer to bicycle off-road rather than on roads, men have shown greater likelihood than women to ride on roads [17]. Older women may favor bicycle paths more than older men do; among younger riders, men may be likelier to prefer fast, direct routes to their destinations, whereas women may prefer bicycle paths and crossings with traffic signals [15].

The primary purpose of this investigation was to identify safety-oriented bicycling practices commonly used by adult riders in an urban locale, so that future research can test whether these practices are protective against crashes. This study also explored whether men and women have different approaches to riding safely. The information obtained in this study addressed both of these study objectives.

The source of information was in-depth interviews with adult bicycle riders in Brooklyn, New York USA, a major urban center. The New York City Department of Transportation [20] has estimated that $25 \%$ of all adult New Yorkers ride bicycles; about half (49\%) of these riders ride at least several times each month. By extrapolation, based on an estimated 2018 adult population of 1,994,000 [21], Brooklyn has approximately 498,500 adult bicycle riders, of whom 244,500 adults ride at least several times monthly. This 
researcher has bicycled in Brooklyn since 1984, including 23 years as a bicycle commuter, and has traveled widely within the borough by bicycle.

Sadly, the need for studies like this one has become much more urgent. The number of bicyclists killed in Brooklyn traffic crashes jumped from two in 2018 to eighteen in 2019, a nine-fold increase [22].

\section{Materials and methods}

\section{Administration of study activities}

This investigation took the form of an interview study. Individuals who self-identified as adult (age 18 or older) experienced bicycle riders in Brooklyn and were conversant in English were eligible to participate in this study. Participants were recruited mainly at bicycle shops (three participants were recruited at other public locations). Recruiting took place in 13 different Brooklyn neighborhoods, to seek a diverse and representative sample of Brooklyn bicycle riders. This researcher approached individuals on location and invited them to participate. Each potential participant was offered an invitation letter, an information sheet explaining the study and their rights as a participant, and a copy of the interview questions. No payments or other inducements to participate were offered. Individuals who agreed to participate were scheduled for a telephone interview to take place at a later time. A few individuals declined to schedule specific interview times but promised to call; none of these individuals were ultimately interviewed.

To ensure anonymity of participants, no identifying information was solicited. To avoid the need to obtain participants' phone numbers, this researcher gave each participant his phone number so that the participant could initiate the interview call from a private and confidential location at the scheduled time. This researcher's phone had no caller ID feature to reveal or record the caller's phone number.

The recruitment objective was to enlist approximately equal numbers of men and women to participate. The total number of participants was dependent on achieving information saturation even if divergent trends occurred between male and female 
participants in the information which they provided. The number of interviews required to achieve saturation could not be predicted with confidence in advance. There is a wide range of views among qualitative researchers; the answer seems to depend on several factors [23]. One investigation specifically designed to address this question [24] found that saturation was achieved by the twelfth interview.

Recruiting and interviewing commenced in early July 2018 and continued until midNovember 2018. Recruiting took place mainly on Saturdays or Sundays, when more riders were expected to visit bicycle shops.

Table 1 summarizes recruitment results by Brooklyn neighborhood. This study experienced a high attrition rate following recruitment: only about one of every four individuals who were recruited took part in an interview. It was particularly challenging to secure participation of minority individuals, and extra recruiting took place in neighborhoods where larger concentrations of minorities live. Despite these efforts, only four self-identified minority individuals were interviewed: two African-American women, one Filipino (Asian) woman, and one Hispanic man. None of the African-American men who were scheduled for interviews followed up to be interviewed.

Table 1. Recruitment and Interviews by Brooklyn Neighborhood.

\begin{tabular}{|lccc|}
\hline Recruitment Location & Recruited & Interviewed & $\%$ interviewed \\
\hline Bay Ridge & 5 & 2 & $40 \%$ \\
Bedford/Stuyvesant & 19 & 0 & $0 \%$ \\
Bushwick & 10 & 3 & $30 \%$ \\
Clinton Hill & 2 & 0 & $0 \%$ \\
Crown Heights & 8 & 1 & $13 \%$ \\
Downtown Brooklyn & 5 & 2 & $40 \%$ \\
Midwood/Marine Park & 7 & 2 & $29 \%$ \\
Park Slope & 7 & 3 & $43 \%$ \\
Prospect Heights & 6 & 4 & $67 \%$ \\
Red Hook & 1 & 0 & $0 \%$ \\
Sheepshead Bay & 4 & 2 & $50 \%$ \\
Sunset Park & 10 & 3 & $30 \%$ \\
Williamsburg & 7 & 2 & $29 \%$ \\
Total & 91 & 24 & $26 \%$ \\
\hline
\end{tabular}


Utilizing a standard set of open-ended questions (the primary interview questions are displayed in the box below), this researcher interviewed each study participant individually by telephone. As necessary, additional follow-up questions were asked during the interviews for further elaboration or clarification. Each interview was audio-recorded, and a written transcript of each interview was produced from the audio-recording.

\section{PRIMARY INTERVIEW QUESTIONS}

From the perspective of safety, what is it like to go bicycle riding in the streets of Brooklyn?

For a bicycle rider in Brooklyn, what are the most common dangers or hazards that confront a bicycle rider? Are there particular things you do while riding to avoid them?

Are there dangers or hazards that are difficult or impossible for a bicycle rider to see and react to? Are there particular things you do while riding to avoid them?

Please describe things you have seen other bicycle riders do that you consider to be dangerous.

If it were your job to teach other adult bicyclists how to stay safe while riding in the streets of Brooklyn, what particular instructions would you give them?

Imagine for a moment that, right now, you are riding on a Brooklyn street along with other traffic. Tell me all the different things you are doing to keep yourself safe and avoid a crash or collision as you ride.

Now I would like to throw out a few words or phrases and ask you if they trigger any additional thoughts about how to ride safely:

Intersections; Traffic signs and signals; Right-of-way; Pedestrians; Speed; Respect; Trucks, buses; Parked cars; "Taking the lane"; Pet peeves. (Participants responded to each word or phrase separately.)

Please feel free to offer any other thoughts about the topics we have discussed today.

\section{Analysis of data}

Thematic analysis was utilized to search for patterns and themes in the interview narratives $[25,26]$. In the initial iteration, in vivo coding was employed to retain as much of the participants' own phrasing as possible [27]. A large number of codes emerged from this first stage of the process; codes were then grouped under more general categories to generate a smaller number of broader themes. All transcripts were then re-coded based on these broader themes.

It was this researcher's view that safety practices which were reported by a larger number of riders would be more likely to gain acceptance and be utilized by the general population of urban bicyclists. Consequently, themes which were retained generally reflected the comments of several participants (often one-third or more). Importantly, the themes represented the most prevalent views among the respondents. The process of 
coding the interview transcripts was facilitated by the use of the comments feature of Microsoft WORD, EXCEL spreadsheets, and QDA Lite software.

To investigate whether men or women were disproportionately represented in individual analyses, the two-tailed Fisher's Exact Test was employed to determine whether the proportions of men and women represented in each analysis were significantly different than the overall proportions of men and women in the study. The statistical results were obtained through the use of a Fisher's Exact Test calculator made available on-line by a now-retired Vassar College Psychology Department faculty member [28]. Significant differences at the $90 \%(p<.10)$ or greater confidence level have been noted.

This study was approved by the Institutional Review Board of State University of New York Downstate Health Sciences University, Brooklyn, New York.

\section{Results}

\section{Demographic profile of the participants (Table 2)}

Table 2. Demographic Profile of the Participants.

\begin{tabular}{|c|c|c|c|c|}
\hline Gender & Men & 14 & Women & 10 \\
\hline \multirow[t]{3}{*}{ Age } & $25-29$ & 5 & $45-49$ & 2 \\
\hline & $30-34$ & 4 & $50-54$ & 4 \\
\hline & $35-39$ & 6 & Over 60 & 3 \\
\hline \multirow[t]{5}{*}{ Race/ethnicity } & White/Caucasian & 14 & Middle Eastern & 1 \\
\hline & White-Italian American & 1 & African-American & 2 \\
\hline & White-Jewish & 1 & Hispanic & 1 \\
\hline & Polish & 1 & Filipino & 1 \\
\hline & Armenian & 1 & Multiple ethnicities & 1 \\
\hline \multirow[t]{3}{*}{ Education } & Some college & 3 & Post-graduate diploma & 2 \\
\hline & Associate's degree & 2 & Master's degree & 8 \\
\hline & Bachelor's degree & 8 & Doctorate & 1 \\
\hline \multirow{3}{*}{$\begin{array}{l}\text { Years since } \\
\text { learning } \\
\text { to ride a bicycle }\end{array}$} & 2 or less & 2 & $30-39$ & 5 \\
\hline & $10-15$ & 1 & 40 or more & 5 \\
\hline & $20-29$ & 10 & (not given) & 1 \\
\hline \multirow{3}{*}{$\begin{array}{l}\text { Years bicycling in } \\
\text { Brooklyn }\end{array}$} & 2 or less & 5 & $11-15$ & 5 \\
\hline & $3-5$ & 5 & 20 or more & 5 \\
\hline & $6-10$ & 4 & & \\
\hline \multirow{2}{*}{$\begin{array}{l}\text { Hours of riding } \\
\text { per week }\end{array}$} & 2 or less & 4 & $4-8$ & 9 \\
\hline & $2-4$ & 7 & 10 or more & 4 \\
\hline Prior crashes* & No & 8 & Yes & 16 \\
\hline
\end{tabular}

${ }^{*}$ involving other vehicles or pedestrians. 
Twenty-four individuals participated in this study, including ten women (42\%). Participants ranged in age from 25 to 75 ; the median age was 37 . Four individuals (17\%) self-identified as racial minorities: two African-Americans, one Hispanic, and one Filipino (Asian). Nineteen participants (79\%) completed at least a four-year college degree program, and eleven of them earned a graduate degree or certificate. Twenty participants (83\%) learned to ride bicycles at least 20 years earlier. The number of years of experience riding in Brooklyn ranged from a few months to approximately 40 years; the median value was 7-8 years. More than half of the participants rode at least 4 hours weekly during the prior twelve months. Two-thirds of the participants had experienced at least one previous crash involving another vehicle or a pedestrian.

\section{Dangers/hazards to bicycle riders}

\section{Dangers/hazards posed by motor vehicles and pedestrians}

Table 3 lists dangers/hazards posed to bicycle riders by motor vehicles and pedestrians which were cited by participants.

Table 3. Dangers/Hazards Cited by Participants.

\begin{tabular}{|lll|}
\hline Category & Specific Hazard & \# Participants \\
\hline $\begin{array}{l}\text { Dangers/hazards posed by } \\
\text { motor vehicles }\end{array}$ & Being doored & 20 (12 men, 8 women) \\
& Turning cars/vehicles & 15 (9 men, 6 women) \\
& Double-parked vehicles & 13 (6 men, 7 women) \\
& Lane incursions & 6 (4 men, 2 women) \\
& Speeding & 4 (3 men, 1 woman) \\
& Running red lights & 3 (1 man, 2 women) \\
\hline $\begin{array}{l}\text { Hazardous pedestrian } \\
\text { behaviors }\end{array}$ & Not paying attention & 10 (5 men, 5 women) \\
& Disregard of rules or other people & 8 (4 men, 4 women) \\
& Unpredictability & 7 (2 men, 5 women; $\boldsymbol{p}=.085)$ \\
& Entering or being in bike lanes & 6 (4 men, 2 women) \\
& Jaywalking & 6 (4 men, 2 women) \\
\hline
\end{tabular}

More than half of the respondents expressed particular concern about three dangers posed by motor vehicles: 
Being doored by someone opening a parked car door (20 participants). Five participants reported that they had been doored themselves. Three others said it had happened to persons they knew.

Turning cars/vehicles (15 participants). Six respondents had themselves been involved in crashes with turning vehicles; one of these respondents had also witnessed such a crash, which he believed had been fatal to the bicyclist involved.

Double-parked vehicles (13 participants). Nine participants commented that doubleparked vehicles forced bicycle riders out into the flow of motorized traffic in order to pass them.

Women were more likely than men to comment explicitly about pedestrian unpredictability. No other gender differences were observed in these results.

\section{Hazardous roadway conditions}

Seven participants cited hazardous roadway conditions, especially potholes, as a safety factor (3 men, 4 women).

\section{Dangerous bicycling practices}

Several bicycling practices were cited as dangerous by participants in this study (Table 4). Most frequently cited were: wrong-way riding, running red lights without making sure it is safe, speeding, riding while distracted, and zigzagging/weaving through traffic. Women were more likely than men to name zigzagging/weaving through traffic as a dangerous bicycling practice.

Table 4. Dangerous Bicycling Practices.

\begin{tabular}{|lc|}
\hline Dangerous Bicycling Practices Cited by Participants & \# Participants \\
\hline Riding the wrong way / Riding against traffic. & 10 (6 men, 4 women) \\
Running red lights without making sure it is safe. & 8 (4 men, 4 women) \\
Riding really fast / Riding too fast under the circumstances. & 8 (4 men, 4 women) \\
Riding while distracted (headphone use, cell phone use, etc.). & 8 (6 men, 2 women $)$ \\
Zigzagging or weaving through traffic. & 7 (2 men, 5 women; $\boldsymbol{p}=.085)$ \\
Not riding in an available bike lane. & 5 (3 men, 2 women) \\
Riding without a helmet. & 5 (2 men, 3 women $)$ \\
\hline
\end{tabular}


Participants generally didn't indicate whether they viewed these bicycling practices as hazardous to themselves and other road users. However, six respondents ( 3 men, 3 women) described how they perceived themselves to be endangered by other riders riding the wrong way toward them.

\section{Safety-oriented practices of participants}

The study participants responded to several questions about their safety-oriented riding behaviors, in general and also in particular situations. Twenty-one themes emerged from analyzing their responses, comprising various practices which participants advocated or utilized themselves while riding.

- Use bike lanes when they are available.

- Take streets with less traffic.

- In general, avoid taking the lane.

- Take the lane when the situation calls for it.

- Go onto the sidewalk if necessary.

- Maintain space between you and parked cars.

- Actively monitor the situation around you.

- Anticipate what will happen or might happen.

- Be very watchful riding near parked cars; look for indications that someone is inside.

- Avoid distraction from listening to an audio device.

- Avoid using your phone and/or texting while riding.

- Signal your intentions.

- Ride in a consistent or otherwise predictable fashion.

- Communicate your presence audibly.

- Use bike lights.

- Look before you go. 
- Don't assume you have the right-of-way.

- Yield right-of-way to pedestrians.

- Adhere to the right-of-way rules.

- Obey traffic signals.

- Don't ride too fast.

The results are presented in Table 5, including a sampling of individual participants' comments to illustrate how the themes were derived. 
Table 5. Safety-Oriented Practices Elicited from Participants.

\begin{tabular}{|c|c|c|c|c|}
\hline \multirow{2}{*}{$\begin{array}{l}\text { Safety-oriented } \\
\text { Practices }\end{array}$} & \multicolumn{3}{|c|}{ Respondents } & \multirow[t]{2}{*}{ Sample Comments } \\
\hline & All & $\mathrm{M}$ & $\mathrm{F}$ & \\
\hline $\begin{array}{l}\text { Use bike lanes } \\
\text { when they are } \\
\text { available. }\end{array}$ & 12 & 5 & 7 & $\begin{array}{l}\text { I have said to, like, friends who have gone biking, that: use the bike lanes as much as possible, like, even if you have to go } \\
\text { a few - like, } 2 \text { blocks up to get on the bike lane even if they have to ride for a while on that street, do that. (Female) } \\
\text { I would have to say, try to plan your route ahead of time - map it out, try to stick to the bike paths as much as possible, } \\
\text { where there is any. (Male) }\end{array}$ \\
\hline $\begin{array}{l}\text { Take streets } \\
\text { with less } \\
\text { traffic. }\end{array}$ & 7 & 4 & 3 & $\begin{array}{l}\text { I would much rather ride a less trafficked street around Green-Wood Cemetery than I would go down, like, 5th Avenue or } \\
\text { 4th Avenue in Brooklyn that doesn't have a bike lane - it's, like, three lanes and heavy traffic. So it's just a less-trafficked } \\
\text { street. (Male) } \\
\text { I tend to avoid - I mean, I occasionally bike to a friend in Fort Greene, and I can be pretty much on back streets. (Female) }\end{array}$ \\
\hline $\begin{array}{l}\text { In general, } \\
\text { avoid taking } \\
\text { the lane. }\end{array}$ & 14 & 8 & 6 & $\begin{array}{l}\text { Oh, no no - I, yeah, never do that. I'm forced to, occasionally, on my commute home because of the narrow streets in } \\
\text { Cobble Hill, and it's something that I'm aware of and I try to move as fast as possible to avoid inconveniencing people, } \\
\text { because drivers can sometimes be quite annoyed when they're stuck behind you, and I will sometimes even move to the } \\
\text { side if there's an empty parking space to, like - So I I'm - I avoid taking the lane as much as I can. (Male) } \\
\text { Yeah, I think that that's just a - you're asking for trouble there, that's just a recipe for disaster. As I said before, many } \\
\text { drivers are - especially in Brooklyn and within the City - many drivers are driving distracted, as well as, there are some who } \\
\text { have some potential road rage issues, so you doing that can just aggravate someone to, you know, a dangerous level, so } \\
\text { I don't recommend that. (Male) }\end{array}$ \\
\hline $\begin{array}{l}\text { Take the lane } \\
\text { when the } \\
\text { situation calls } \\
\text { for it. }\end{array}$ & 8 & 4 & 4 & $\begin{array}{l}\text { I do that often, when there are situations that - especially a lot of roads in New York City and Brooklyn you know, there's } \\
\text { only - as a cyclist, you can go probably even faster than a car, because of traffic conditions, so if it's not safe to be I think } \\
\text { it's more unsafe to, like, try to, you know, stay on the side and let a car come close to you, than to just - when you're not } \\
\text { going to slow a car down, you may as well take the lane - I think it's safer. And then as soon as it's - you know, usually I do } \\
\text { that if it's, like, going around a double-parked car. I do it because it's - you know, and cars usually, I find, always respect } \\
\text { it. I've never - I feel like l've never been beeped at or anything like that, I take the lane and as soon as the road is clear, I } \\
\text { get back on the (unintelligible word) to where the bike lane is. (Male) } \\
\text { So I think in certain cases, especially when speeds are slow and everyone's more or less traveling at the same speed, it } \\
\text { can be much safer just to make your presence really known, because I think sometimes that's the more risky thing is } \\
\text { when people don't realize that you're there, they're kind of (unintelligible) bikers, and you feel like cars will, like, you know - } \\
\text { they'll still pull out from being parked or they'll, you know, try to make a turn into you, not seeing that you're coming up in } \\
\text { the bike lane. So I think there are - in certain cases, I think taking the lane is safer because you're more visible. (Female) }\end{array}$ \\
\hline $\begin{array}{l}\text { Go onto the } \\
\text { sidewalk if } \\
\text { necessary. }\end{array}$ & 5 & 3 & 2 & $\begin{array}{l}\text { If you feel unsafe, and there's, like, too many cars blocking the street, like, too much traffic, go on the sidewalk - and just } \\
\text { be slow and, like, be respectful of pedestrians, because your safety is more important than, like, risking being on the } \\
\text { roadway. (Female) } \\
M \text { If things are extremely packed on the street, I will go on an empty sidewalk. (Male) }\end{array}$ \\
\hline $\begin{array}{l}\text { Maintain space } \\
\text { between you } \\
\text { and parked } \\
\text { cars. }\end{array}$ & 11 & 7 & 4 & $\begin{array}{l}\text { It's front-of-mind for me often, so I just try to maintain as much distance between my bike and the cars that I can, while } \\
\text { staying in, like, the bike lane. (Female) } \\
\text { I'm generally not biking within, like, less than three feet of, like, the parked cars that are next to my side, just so that if } \\
\text { anything is to happen, you know, like with a door opening, I'm kind of outside of that. (Male) }\end{array}$ \\
\hline
\end{tabular}


Table 5 continued. Safety-Oriented Practices Elicited from Participants.

\begin{tabular}{|c|c|c|c|c|}
\hline \multirow{2}{*}{$\begin{array}{l}\text { Safety-oriented } \\
\text { Practices }\end{array}$} & \multicolumn{3}{|c|}{ Respondents } & \multirow[t]{2}{*}{ Sample Comments } \\
\hline & All & $\mathbf{M}$ & $\mathbf{F}$ & \\
\hline $\begin{array}{l}\text { Actively } \\
\text { monitor the } \\
\text { situation } \\
\text { around you. }\end{array}$ & 14 & 7 & 7 & $\begin{array}{l}\text { Keeping my eyes up at the one-ways and where the traffic's going to be coming from, keeping my eyes and ears on the } \\
\text { other traffic signs or traffic lights, stop lights, and see where - you know - making sure I know I will be able to go through a } \\
\text { red - or go through a green light safely, and just keep my - you know, keep my awareness also to the back of me, and just } \\
\text { making - keep my ears and senses open just to hear and see what's coming behind me. (Male) } \\
\text { I am constantly sort of scanning my surroundings, being aware of cars that are parked and potentially opening doors, cars } \\
\text { that are signaling to turn - for instance, they'll just, like, soar right into the bike lane to turn, without realizing that you are } \\
\text { (garbled). (Female) }\end{array}$ \\
\hline $\begin{array}{l}\text { Be very } \\
\text { watchful riding } \\
\text { near parked } \\
\text { cars; look for } \\
\text { indications that } \\
\text { someone is } \\
\text { inside. }\end{array}$ & 12 & 7 & 5 & $\begin{array}{l}\text { [Parked cars] Watch for those doors. And, there's not many people signal before they pull out of a parking spot, so I } \\
\text { always try to check and see if there's a driver sitting in the seat of a parked car. (Male) } \\
\text { Kind of, like, keep an eye on it. You know, just like - If you see, if I see, like, the brake light on or the door, like, half open } \\
\text { or, like, cracked open or, like, if the window is open, I know there is someone in the car who might open the door, or if I see } \\
\text { a pedestrian, like, right by the car, then I can, you know, imagine that he will come in and out of the car. So it's just, yeah - } \\
\text { just, like, paying attention, I guess. (Female) }\end{array}$ \\
\hline $\begin{array}{l}\text { Avoid } \\
\text { distraction } \\
\text { from listening } \\
\text { to an audio } \\
\text { device. }\end{array}$ & 11 & 7 & 4 & $\begin{array}{l}\text { Don't have your music in your ears at all - don't have anything in your ears at all. Because you need as much, you know - } \\
\text { as much of your periphery sensors as possible. (Male) } \\
\text { If I'm listening to music, I have one headphone in and one out, so I can hear traffic around me. (Male) }\end{array}$ \\
\hline $\begin{array}{l}\text { Avoid using } \\
\text { your phone } \\
\text { and/or texting } \\
\text { while riding. }\end{array}$ & 5 & 4 & 1 & $\begin{array}{l}\text { I don't have my phone anywhere -- like, I don't -- I have it sometimes mounted on my on my bike if I don't have a watch } \\
\text { on, I mean, and I only use it for a timekeeping device, but I do not talk on my phone, I do not listen to my music, I do not, } \\
\text { like, use a GPS on it. If I have to, like if I have to take my eyes off the road, I will pull over and look at my phone if I, like, } \\
\text { look at a map or GPS or something. (Male) } \\
\text { Do not be distracted, do not answer your phone or look down to your phone..... And, yeah, just try not to be distracted. } \\
\text { I've witnessed a person text-messaging while riding and flipped his bike over because he wasn't aware that there was a } \\
\text { lady crossing with a young child in front of him slammed on the brakes, flipped over. (Male) }\end{array}$ \\
\hline
\end{tabular}


Table 5 continued. Safety-Oriented Practices Elicited from Participants.

\begin{tabular}{|c|c|c|c|c|}
\hline \multirow{2}{*}{$\begin{array}{l}\text { Safety-oriented } \\
\text { Practices }\end{array}$} & \multicolumn{3}{|c|}{ Respondents } & \multirow[t]{2}{*}{ Sample Comments } \\
\hline & All & $\mathbf{M}$ & $\mathbf{F}$ & \\
\hline $\begin{array}{l}\text { Signal your } \\
\text { intentions. }\end{array}$ & 9 & 5 & 4 & $\begin{array}{l}\text { M And to be predictable like, to not just be like - if you're going to do something, you want to be signaling..... (Male) } \\
\text { If I can safely signal, you know, then I do. If I can signal without, say, losing my balance or something, I try to signal and } \\
\text { act in a way that can be anticipated by the other vehicles. (Female) }\end{array}$ \\
\hline $\begin{array}{l}\text { Ride in a } \\
\text { consistent or } \\
\text { otherwise } \\
\text { predictable } \\
\text { fashion. }\end{array}$ & 7 & 3 & 4 & $\begin{array}{l}\text { Also staying in a, like, predictable place on the road, so, you know, I'm not, like, you know, wobbling back and forth, so } \\
\text { people know, like, where I'm going and, like, this is my path. (Female) } \\
\text { So if I'm riding down the street right now, I'm trying to dictate my domain - where I'm going. I'm not, you know, erratic, } \\
\text { where I'm going fast and then slow, I'm not erratic where I'm going left and right, I try to stay straight. (Male) }\end{array}$ \\
\hline $\begin{array}{l}\text { Communicate } \\
\text { your presence } \\
\text { audibly. }\end{array}$ & 10 & 4 & 6 & $\begin{array}{l}\text { I have a bell, I yell, you know. And I find the bell isn't always useful. You have to - you have to yell. (Male) } \\
\text { I use my little beeper thingee, because people don't pay attention in New York - and they are all going to work crossing on } \\
\text { red light. (Female) }\end{array}$ \\
\hline Use bike lights. & 10 & $3^{*}$ & $7^{*}$ & $\begin{array}{l}\text { I have lights - I have } 3 \text { different lights: I have one for headlight, I have a taillight, and I have, like, another spare one that I'll } \\
\text { either use as another taillight or I'll put it on my helmet, as well as - like, a headlamp - kind of flashlight, which I use in the } \\
\text { darker times. (Male) } \\
\text { Make yourself visible - lights, a blinking red light, even in the daytime, can be a real plus in terms of visibility...... I've got a } \\
\text { helmet which has a little blinky light on top, as well as some reflective stuff. And, particularly at night, I'll use that, because } \\
\text { it may put me more in the line of vision than the lower-down blinky lights. (Female) }\end{array}$ \\
\hline $\begin{array}{l}\text { Don't assume } \\
\text { you have the } \\
\text { right-of-way. }\end{array}$ & 13 & 7 & 6 & $\begin{array}{l}\text { Right-of-way - Assume that drivers won't respect your signaling or right-of-way. I've had many times I signal and start a } \\
\text { lane change and a driver will just go through. So cars always have the right-of-way - and police, double! (Male) } \\
\text { Don't expect pedestrians or cars to yield to you - you should take control and ride safely around them. (Male) }\end{array}$ \\
\hline
\end{tabular}


Table 5 continued. Safety-Oriented Practices Elicited from Participants.

\begin{tabular}{|c|c|c|c|c|}
\hline \multirow{2}{*}{$\begin{array}{l}\text { Safety-oriented } \\
\text { Practices }\end{array}$} & \multicolumn{3}{|c|}{ Respondents } & \multirow[t]{2}{*}{ Sample Comments } \\
\hline & All & $\mathbf{M}$ & $\mathbf{F}$ & \\
\hline $\begin{array}{l}\text { Yield right-of- } \\
\text { way to } \\
\text { pedestrians. }\end{array}$ & 8 & 5 & 3 & $\begin{array}{l}\text { They pretty much have the right-of-way. You know, when I come to a crosswalk and someone's walking by, I don't go past } \\
\text { them, I don't try to, you know - I stop and let them cross in front of me. (Male) } \\
\text { You still have to have an utmost respect for people that are crossing in that crosswalk. And I think that's a real concern } \\
\text { that I see, it's an unfortunate - and I think that's why cyclists really earn a little bit of their - the ire of, you know, the public. I } \\
\text { think - I think - you know, the interaction with cars is one thing, but to interact with people that are on the streets walking or, } \\
\text { you know, doing other forms of exercise like running - yeah, I think that's a big prob- to me, that's - that's my biggest issue } \\
\text { with cyclists and how they interact with pedestrians - not so much how they interact with cars, but how they interact with } \\
\text { pedestrians. (Male) }\end{array}$ \\
\hline $\begin{array}{l}\text { Adhere to the } \\
\text { right-of-way } \\
\text { rules. }\end{array}$ & 5 & 4 & 1 & $\begin{array}{l}\text { Right-of-way You know - cars, pedestrians, school buses, buses - you know - you've got to respect who has it. (Male) } \\
\text { I mean, same as cars, right? I just generally obey the car traffic laws when it comes to right-of-way. (Female) }\end{array}$ \\
\hline $\begin{array}{l}\text { Obey traffic } \\
\text { signals. }\end{array}$ & 11 & 6 & 5 & $\begin{array}{l}\text { I wouldn't encourage them to go through a red light. I've been stopped myself a couple of times for this, but I would } \\
\text { certainly say you should always slow down and be aware of what's coming. If it's not your light, you shouldn't be going } \\
\text { through, cutting off pedestrians or cutting off cars. It's - I think that's probably the number one advice I would give. (Male) } \\
\text { I do, though, like, stop at lights almost all the time. There are occasions when I don't, but for the most part, I feel like, by } \\
\text { observing those kind of general rules that it makes it easy to convince people that it's more predictable for other people, } \\
\text { and it makes it more predictable for you, you know? (Male) }\end{array}$ \\
\hline $\begin{array}{l}\text { Don't ride too } \\
\text { fast. }\end{array}$ & 14 & 6 & 8 & $\begin{array}{l}\text { I don't - I don't cycle fast. I'm not in a hurry, so I would keep - I see no reason to go faster than } 15 \text { miles an hour. Speed } \\
\text { will only increase, I suppose, the chances of something wrong happening. (Male) } \\
\text { So that's what I think of when I think of speed - going too fast and not being able to quickly stop and not being able to } \\
\text { swerve. (Female) }\end{array}$ \\
\hline
\end{tabular}




\section{Other safety-related considerations}

\section{Giving and receiving respect}

Participants were asked to respond to the concept respect (Table 6). A majority of participants advocated being respectful to all other road users. However, eight participants, including seven women, asserted that bicycle riders or bike lanes don't receive the respect that they deserve; this gender difference was statistically highly significant.

Table 6. Attitudes about Respect.

Respect other road users.

Sample Responses:

Respondents $=14$ (10 men, 4 women)

I mean, that's a big one for me, I guess. Just, you know respect everyone that's out on the road, everyone has somewhere to go just like yourself and, you know, if you, I feel like as a cyclist, if you are gracious towards cars, that, you know, they'll look out for you or other cyclists in the future, and, instead of, you know - I've seen cyclists, like, smack car doors and things like that, and that really irritates me, because it's - that's not helping anyone, that's just, you know, creating a culture of drivers that hate cyclists. (Male)

The main thing is that you've got to have just a level of respect for everybody that's out on the road - that's first and foremost to me I mean - I - I don't - I don't feel it's necessary to impose your will or your agenda on anyone else. I think you could take care of your own business - I think you can take, you know - do what you need to do as a cyclist and not put anybody in, like, you know, a dangerous situation, or even an inconvenient - or a situation where they're just not happy with you. Yeah, respect for - respect for others really is my biggest thing. (Male)

Bicycle riders and bicycle lanes don't get enough respect.

Sample Responses:

Respondents $=8$ (1 man, 7 women; $\boldsymbol{p}=.002)$

Respect - you know, what I said about that, like: that people don't care. And yeah, I think that I get annoyed sometimes by that. I'm just, like - You can see that I am here, and, like, why are you pretending that I am not there? You know, it's just that - I think that is actually the thing that annoys me the most because sometimes they can put me and them in, like, dangerous situations just because they pretend that I'm not there. (Female)

This is a good one, because I feel like there is not much respect for our bike - you know, for riders and bike culture in New York - more and more, but - cars - there needs to be more respect, especially for the infrastructure and bike lanes so we can bike safer. (Female)

\section{Helmet use}

Eleven participants, including eight women $(p=.011)$, advocated helmet use as a safety practice for bicycle riders. While this practice is not directly related to crash avoidance, it is widely recognized to prevent serious head injuries. 


\section{Discussion}

\section{Derivation of safety-oriented bicycling strategies}

In the urban landscape of Brooklyn, New York, bicycle riders, drivers, and pedestrians co-exist within very tight spaces, many are in a hurry, and some may not be watching out for others. A bicycle rider is often challenged to ride safely among the plethora of hazards described by the participants. Twenty-two specific riding practices meant to reduce crash risk appeared to be prevalent among the participants in this study. Based on these practices, it is possible to postulate a manageable number of safety-oriented bicycling strategies for adult bicycle riders to employ in Brooklyn or other urban settings.

Minimize exposure to other road users, especially motor vehicles, while riding. Twelve individuals favored using bike lanes when they are available, and seven individuals said that they tried to avoid streets with a lot of traffic. Similar bicyclist route preferences have been reported by other recent studies [29-31], and evidence suggests that crash risk may be reduced by using bike lanes [32] or avoiding challenging traffic situations [33-35].

These two practices suggest a more general strategy: reduce exposure to other road users, especially motor vehicles. The same objective may be achieved in a number of different ways. Five respondents reported that they sometimes found it expedient to go onto the sidewalk to escape difficult traffic situations (however, riding on the sidewalk is illegal in New York City). Another method was described by a female participant:

I try not to pass cars more often than I need to ... so what I try to do is time my riding such that, either, like, maybe I'm the last car or the last vehicle, like, through an intersection on the light like, I'll try to make the light so that way I can ride for the next block without any other cars coming up behind me - sometimes I try, like, to speed up or slow down based on that.

It must be acknowledged that reducing exposure to other road users is not always straightforward. Perhaps the most difficult issue for a bicycle rider in Brooklyn is where to position oneself in the roadway while riding. Fourteen participants expressed a preference for riding toward the side of the road rather than in the traffic lane (seven individuals worried specifically about drivers becoming angry or impatient due to their presence in the traffic 
lane). On the other hand, eight respondents advocated taking the lane when the situation calls for it. Because parked cars are present on most Brooklyn streets, riding toward the side of the road may increase crash risk [36]. The possibility of being doored is a frequent danger [37] which was recognized by many respondents. Eleven participants said they try to maintain space between themselves and parked cars when they ride. As one male participant noted, though, avoiding the door zone and the flow of traffic concurrently can be challenging:

You don't want to be, let's say, 12 inches from a parked car, all right? So you want to give yourself a healthy space from cars that are parked, but also you don't want to be in the middle of the street. So it's a little bit of that dance that we do when we're trying to be in a safe spot.

Be vigilant and anticipate what others might do. Almost all participants explicitly cited the need to stay alert and pay attention. Fourteen individuals described practices related to actively monitoring what is happening around them; some respondents mentioned listening as well as watching. Anticipating what would or might happen was also cited as a safety practice by fourteen participants. Twelve individuals said they were especially watchful near parked cars (some described clues they looked for to indicate whether someone might be inside). Eleven individuals recognized that listening to music while riding would impair situational awareness, and five respondents cited risks of cell phone use and/or texting while riding. (Electronic device use while riding has been shown to increase crash odds among teen and young adult bicycle riders [33].) Although a previous study [14] did not find an association between vigilance and reduced traffic accident involvement, further research is warranted.

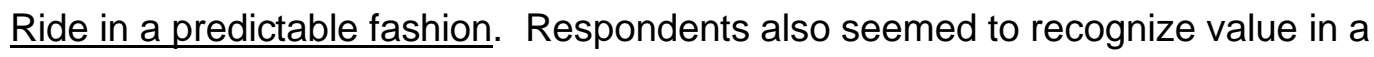
corollary objective: enabling other road users to predict the bicycle rider's actions in traffic. Predictability as a strategy emanated from two specific categories of participant commentary: using hand signals to indicate intended moves such as turns (9 participants) and riding in a consistent or otherwise predictable fashion (7 participants). Prior research has suggested that predictability may be associated with reduced traffic accident 
involvement [14]. Research has also shown that, in the absence of signaling by a bicyclist, someone following behind him/her may have difficulty predicting that the bicyclist is about to turn, as well as difficulty predicting the direction of the turn [38].

Make presence known to other road users. Another corollary strategy involves making one's presence known to other road users. Ten respondents reported using a bell or voice to alert others nearby, and ten respondents also reported using bike lights. Making one's presence known can involve a variety of measures, both passive and active. The safety benefits of passive visibility aids such as bike lights and brightly-colored or reflective apparel have been demonstrated by one study [39] although not by others [40-42]. No studies were found concerning active measures such as sounding a bell or yelling.

Make sure it is safe before proceeding. This strategy was suggested by participant commentary concerning looking before proceeding and right-of-way. Eleven individuals spoke explicitly about looking before going, especially at intersections. While five individuals advocated adherence to right-of-way rules, thirteen respondents stated that a rider should not assume that he/she has the right-of-way, and eight individuals maintained that bicycle riders should always yield to pedestrians.

Obey traffic rules. Ten respondents spoke in favor of obeying traffic lights. In addition, ten individuals spoke out against wrong-way riding, and six respondents reported that wrong-way riders had posed hazards to them while they were riding. Some studies have shown an association between higher risk of crashes and bicyclists disobeying traffic signals and signs [35, 43-45].

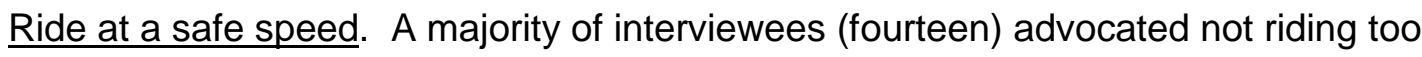
fast. Previous studies have implicated speed as a factor in bicyclist injuries due to crashes [46] and as a factor in more serious bicycle-vehicle conflicts for male riders at urban intersections [18]. 


\section{Consideration of gender differences in the results}

Caution is required when drawing conclusions from the statistical tests of gender differences in the participants' commentaries. If fifteen individuals discussed a particular idea, this does not necessarily mean that the other nine individuals had a different view of it; we might presume that they deemed it less important, but even this may not be true. In the statistical analysis, the tests may have missed some gender differences: with a small number of participants, statistical significance could only be achieved by relatively large differences in the number of comments by women versus men. Conversely, more than 40 individual statistical tests were computed during the analysis. At the $90 \%$ confidence level, one of every ten statistical tests could be significant by pure chance.

Across the board, most dangers/hazards and dangerous bicyclist behaviors were equally likely to be identified by either men or women in this sample of participants. Only two issues appeared to be on women's radars more than on men's $(p<.10)$ : pedestrian unpredictability and bicyclist zigzagging or weaving through traffic. Since these two significant results arose among many statistical tests, both may be spurious outcomes. Any attempt to explain these apparent gender differences would be speculative.

Overall, men and women in this study also advocated and/or utilized the same safety-oriented bicycling practices. Among all the safety-related practices identified in the analysis, only three practices showed significant gender differences: women were more likely than men to (1) advocate using bike lights, (2) state or imply that looking before you go is an important safety tactic, and (3) advocate wearing a helmet. Although these results may be spurious, they could instead indicate that female bicyclists are more cautious than male bicyclists, as prior studies have suggested $[15,16]$. However, riding experience may be a confounding factor. In this sample of respondents, the men had generally ridden bicycles in Brooklyn longer than the women had: 10 of the 12 participants above the median for years riding in Brooklyn were men $(p=.036)$. In addition, 10 of the 13 participants who reported riding at least 4-8 hours per week during the previous twelve months were men $(p=.095)$. 
The lack of respect reported by women who participated in this study supports an assertion that women have greater concerns about motorist aggression, as a previous study reported [17]. Motorist aggression, especially harassment, should be treated as a very serious public safety issue. One participant offered a disturbing account of being harassed while she rode:

I wish people had more (respect). It also sucks being, like, a female bike rider and being, like, cat-called and followed while you're on your bike. Like, that's happened to me lots of times, and, like, I don't know, they just, like - there was one time, like, this car followed me, like, it kept on following me every intersection, and then he said, like, these nasty things to me, and I'm, like, $f--k$ it, I'm just going to go into the intersection so this car won't follow me anymore. Yeah, I feel like it's a whole other level of, like, disrespect to be, like, put in such a position of vulnerability where, like, someone's, you know, saying these things to you and also in a car, and if you, like, say anything back, they could, like, run you over. So, respect, I hope people have more of it.

Research into motorist harassment of riders based on gender or any other demographic characteristic should be given high priority.

\section{Conclusions}

The purpose of employing safety-oriented bicycling practices is to minimize the likelihood of a crash or collision with another road user. This interview study afforded an opportunity to learn about the safety practices of 24 bicycle riders in Brooklyn, New York. Based on the interviews, seven strategies for safe riding were identified. Now it is important, through additional research, to develop and refine these concepts and to learn whether or not they offer protection against crashes.

Several limitations must be recognized. It was beyond the scope of this study to demonstrate that any particular safety-oriented strategy or practice is associated with reduced traffic crashes. Geographically, this study was limited to a single urban locale; findings from this study may not be transferable to non-urban settings, perhaps not even to other urban settings. The under-representation of minorities and the absence of African- 
American men, as well as the possible over-representation of riders with college and postgraduate educations, may have restricted our understanding of the bicycle riding experience in Brooklyn and the most appropriate strategies for safe riding. This researcher was male; a female researcher might have been more effective in both recruiting female participants and eliciting information from them in the interviews. Furthermore, there were moments during some interviews when additional follow-up questions could have clarified participant statements which later proved to be unclear or ambiguous. It is also impossible to rule out investigator bias. This researcher tried not to distort or overreach the data; nevertheless, this researcher's personal experiences as a bicycle rider undoubtedly influenced the construct of the interview questions as well as the conceptualization of safety-oriented bicycling practices and strategies during the analysis.

\section{Acknowledgments}

Sincere thanks go to the 24 participants for their willingness to be interviewed. This researcher appreciates their valuable perspectives and wishes them safe journeys always. This researcher is also grateful for the support and encouragement received from bicycle shop managers and employees where recruiting took place. This researcher also thanks Susan Holman and Laura Welder for their advice and guidance on conducting qualitative research; Ms. Welder also offered valuable feedback on the manuscript.

\section{References}

1. Feenstra H, Ruiter RAC, Kok G. Social-cognitive correlates of risky adolescent cycling behavior. Bmc Public Health. 2010;10. doi: 10.1186/1471-2458-10-408. PubMed PMID: WOS:000281862200002.

2. Feenstra H, Ruiter RAC, Schepers J, Peters G-J, Kok G. Measuring risky adolescent cycling behaviour. International Journal of Injury Control and Safety Promotion. 2011;18(3):181-7. doi: 10.1080/17457300.2010.540334. PubMed PMID: WOS:000299792100003.

3. Bosehans G, Massola GM. Commuter cyclists' risk perceptions and behaviour in the city of Sao Paulo. Transportation Research Part F-Traffic Psychology and Behaviour. 2018;58:414-30. doi: 10.1016/j.trf.2018.06.029. PubMed PMID: WOS:000447357900036. 
4. Useche S, Montoro L, Alonso F, Oviedo-Trespalacios O. Infrastructural and Human Factors Affecting Safety Outcomes of Cyclists. Sustainability. 2018;10(2). doi: 10.3390/su10020299. PubMed PMID: WOS:000425943100022.

5. Useche SA, Alonso F, Montoro L, Esteban C. Explaining self-reported traffic crashes of cyclists: An empirical study based on age and road risky behaviors. Safety Science. 2019;113:105-14. doi: 10.1016/j.ssci.2018.11.021. PubMed PMID: WOS:000457506300011.

6. Useche SA, Montoro L, Alonso F, Tortosa FM. Does gender really matter? A structural equation model to explain risky and positive cycling behaviors. Accident Analysis and Prevention. 2018;118:86-95. doi: 10.1016/j.aap.2018.05.022. PubMed PMID: WOS:000439672000010.

7. Twisk DAM, Commandeur JJF, Vlakveld WP, Shope JT, Kok G. Relationships amongst psychological determinants, risk behaviour, and road crashes of young adolescent pedestrians and cyclists: Implications for road safety education programmes. Transportation Research Part F-Traffic Psychology and Behaviour. 2015;30:45-56. doi: 10.1016/j.trf.2015.01.011. PubMed PMID: WOS:000353855000005.

8. Twisk D, Wesseling S, Vlakveld W, Vissers J, Hegeman G, Hukker N, et al. Higherorder cycling skills among 11-to 13-year-old cyclists and relationships with cycling experience, risky behavior, crashes and self-assessed skill. Journal of Safety Research. 2018;67:137-43. doi: 10.1016/j.jsr.2018.10.003. PubMed PMID: WOS:000455064700017.

9. Hezaveh AM, Zavareh MF, Cherry CR, Nordfjaern T. Errors and violations in relation to bicyclists' crash risks: Development of the Bicycle Rider Behavior Questionnaire (BRBQ). Journal of Transport \& Health. 2018;8:289-98. doi: 10.1016/j.jth.2017.11.003. PubMed PMID: WOS:000431077800033.

10. Puchades VM, Pietrantoni L, Fraboni F, De Angelis M, Prati G. Unsafe cycling behaviours and near crashes among Italian cyclists. International Journal of Injury Control and Safety Promotion. 2018;25(1):70-7.

11. Bacchieri G, Barros AJD, dos Santos JV, Gigante DP. Cycling to work in Brazil: Users profile, risk behaviors, and traffic accident occurrence. Accident Analysis and Prevention. 2010;42(4). doi: 10.1016/j.aap.2009.12.009. PubMed PMID: WOS:000278504700006.

12. Naevestad T-O, Elvebakk B, Bjornskau T. Traffic safety culture among bicyclists Results from a Norwegian study. Safety Science. 2014;70:29-40. doi: 10.1016/j.ssci.2014.04.0200925-7535. PubMed PMID: WOS:000343361400004.

13. Hatfield J, Dozza M, Patton DA, Maharaj P, Boufous S, Eveston T. On the use of naturalistic methods to examine safety-relevant behaviours amongst children and evaluate a cycling education program. Accident Analysis and Prevention. 2017;108:91-9. doi: 10.1016/j.aap.2017.08.025. PubMed PMID: WOS:000413385800011.

14. Hoglund MW. Safety-oriented bicycling and traffic accident involvement. IATSS Research 2018;42(3):152-62. Epub November 10, 2017.

15. Bernhoft IM, Carstensen G. Preferences and behaviour of pedestrians and cyclists by age and gender. Transportation Research Part F-Traffic Psychology and Behaviour. 2008;11(2):83-95. doi: 10.1016/j.trf.2007.08.004. PubMed PMID: WOS:000253731100001.

16. Felonneau ML, Causse E, Constant A, Contrand B, Messiah A, Lagarde E. Gender stereotypes and superior conformity of the self in a sample of cyclists. Accident Analysis and 
Prevention. 2013;50:336-40. doi: 10.1016/j.aap.2012.05.006. PubMed PMID: WOS:000314191600039.

17. Heesch KC, Sahlqvist S, Garrard J. Gender differences in recreational and transport cycling: a cross-sectional mixed-methods comparison of cycling patterns, motivators, and constraints. International Journal of Behavioral Nutrition and Physical Activity. 2012;9. doi: 10.1186/1479-5868-9-106. PubMed PMID: WOS:000311625100001.

18. Stipancic J, Zangenehpour S, Miranda-Moreno L, Saunier N, Granie MA. Investigating the gender differences on bicycle-vehicle conflicts at urban intersections using an ordered logit methodology. Accident Analysis and Prevention. 2016;97:19-27. doi: 10.1016/j.aap.2016.07.033. PubMed PMID: WOS:000390634300002.

19. Garrard J, Rose G, Lo SK. Promoting transportation cycling for women: The role of bicycle infrastructure. Preventive Medicine. 2008;46(1):55-9. doi: 10.1016/j.ypmed.2007.07.010. PubMed PMID: WOS:000253467200011.

20. Bicyclists: Network and Statistics: Ridership Statistics. New York City Department of Transportation. [Cited 2019 June 22]. Available

from: https://www1.nyc.gov/html/dot/html/bicyclists/bikestats.shtml\#statistics.

21. United States Census Bureau. QuickFacts: New York city, New York; Kings County (Brooklyn Borough), New York; United States. [Cited 2019 June 22]. Available from: https://www.census.gov/quickfacts/fact/table/newyorkcitynewyork,kingscountybrooklynborou ghnewyork,US.

22. Duggan K. Trucker fatally strikes cyclist in Williamsburg: NYPD. Brooklyn Paper. 2020 Jan 31 [Cited 2020 Feb 8]. Available from: https://www.brooklynpaper.com/truckerfatally-strikes-cyclist-in-williamsburg-nypd/.

23. Baker SE, Edwards R. How many qualitative interviews is enough? Expert voices and early career reflections on sampling and cases in qualitative research [Cited $2018 \mathrm{Apr}$ 6]. Available from: http://eprints.ncrm.ac.uk/2273/4/how many interviews.pdf.

24. Guest G, Bunce A, Johnson L. How many interviews are enough? An experiment with data saturation and variability. Field Methods. 2006;18(1):59-82.

25. Boyatzis RE. Transforming qualitative information: Thematic analysis and code development. Thousand Oaks, Califo: SAGE Publications, Inc. ; 1998.

26. Strauss A, Corbin J. Basics of qualitative research: grounded theory procedures and techniques. Newbury Park, California: SAGE Publications, Inc.; 1990.

27. Saldana J. The Coding Manual for Qualitative Researchers. Second ed. London, United Kingdom: SAGE Publications; 2013.

28. Lowry R. The Fisher Exact Probability Test (Subchapter 8a). 1998-2019. In: Concepts and Applications of Inferential Statistics [Internet]. [Cited 2019 June 7]. Available from: www.vassarstats.net/textbook/index.html.

29. Majumdar BB, Mitra S. Valuing Factors Influencing Bicycle Route Choice Using a Stated-Preference Survey. Journal of Urban Planning and Development. 2017;143(3). doi: 10.1061/(asce)up.1943-5444.0000380. PubMed PMID: WOS:000415350400001.

30. Vedel SE, Jacobsen JB, Skov-Petersen H. Bicyclists' preferences for route characteristics and crowding in Copenhagen - A choice experiment study of commuters. 
Transportation Research Part a-Policy and Practice. 2017;100:53-64. doi: 10.1016/j.tra.2017.04.006. PubMed PMID: WOS:000403127000005.

31. Lu W, Scott DM, Dalumpines R. Understanding bike share cyclist route choice using GPS data: Comparing dominant routes and shortest paths. Journal of Transport Geography. 2018;71:172-81. doi: 10.1016/j.jtrangeo.2018.07.012. PubMed PMID:

WOS:000447112400014.

32. Chen L, Chen C, Srinivasan R, McKnight CE, Ewing R, Roe M. Evaluating the Safety Effects of Bicycle Lanes in New York City. American Journal of Public Health.

2012;102(6):1120-7. doi: 10.2105/ajph.2011.300319. PubMed PMID:

WOS:000304723200017.

33. Goldenbeld C, Houtenbos M, Ehlers E, De Waard D. The use and risk of portable electronic devices while cycling among different age groups. Journal of Safety Research. 2012;43(1). doi: 10.1016/j.jsr.2011.08.007. PubMed PMID: WOS:000302040600001.

34. Puchades VM, Fassina F, Fraboni F, De Angelis M, Prati G, de Waard D, et al. The role of perceived competence and risk perception in cycling near misses. Safety Science. 2018;105:167-77. doi: 10.1016/j.ssci.2018.02.013. PubMed PMID: WOS:000428823800017.

35. Hollingworth MA, Harper AJL, Hamer M. Risk factors for cycling accident related injury: The UK Cycling for Health Survey. Journal of Transport \& Health. 2015;2(2):189-94. doi: 10.1016/j.jth.2015.01.001. PubMed PMID: WOS:000357223700016.

36. Hatfield J, Poulos RG, Rissel C, Flack LK, Grzebieta R, Mclntosh AS, et al. Factors associated with cyclists' self-reported choice of lane position. Transportation Research Part F-Traffic Psychology and Behaviour. 2018;55:403-14. doi: 10.1016/j.trf.2018.03.016. PubMed PMID: WOS:000432641100036.

37. Lawrence BM, Oxley JA, Logan DB, Stevenson MR. Cyclist exposure to the risk of car door collisions in mixed function activity centers: A study in Melbourne, Australia. Traffic Injury Prevention. 2018;19(S1):S164-S8.

38. Westerhuis F, De Waard D. Reading cyclist intentions: Can a lead cyclist's behaviour be predicted? Accident Analysis and Prevention. 2017;105:146-55. doi:

10.1016/j.aap.2016.06.026. PubMed PMID: WOS:000404321600018.

39. Lahrmann H, Madsen TKO, Olesen AV, Madsen JCO, Hels T. The effect of a yellow bicycle jacket on cyclist accidents. Safety Science. 2018;108:209-17. doi: 10.1016/j.ssci.2017.08.001. PubMed PMID: WOS:000436885000019.

40. Tin ST, Woodward A, Ameratunga S. Incidence, risk, and protective factors of bicycle crashes: Findings from a prospective cohort study in New Zealand. Preventive Medicine. 2013;57(3):152-61. doi: 10.1016/j.ypmed.2013.05.001. PubMed PMID: WOS:000324011500002.

41. Miller PD, Kendrick D, Coupland C, Coffey F. Use of conspicuity aids by cyclists and risk of crashes involving other road users: Population based case-control study. Journal of Transport \& Health. 2017;7:64-74. doi: 10.1016/j.jth.2017.03.008. PubMed PMID: WOS:000419239600009.

42. Hoffman MR, Lambert WE, Peck EG, Mayberry JC. Bicycle Commuter Injury Prevention: It Is Time to Focus on the Environment. Journal of Trauma-Injury Infection and Critical Care. 2010;69(5). doi: 10.1097/TA.0b013e3181f990a1. PubMed PMID: WOS:000284110100027. 
43. Hagemeister $\mathrm{C}$, Bunte $\mathrm{H}$, Brammer $\mathrm{N}$, Wagner $\mathrm{P}$. Protecting or harming oneself: options of older cyclists to cycle safely. Abstract, International Cycling Safety Conference 2014, Gothenburg, Sweden2014.

44. Bjornskau T. Summary: Cycle accidents among teenagers. TOI report 504/2001, Institute of Transport Economics, Oslo, Norway.

45. Robartes E, Chen TD. Crash histories, safety perceptions, and attitudes among Virginia bicyclists. Journal of Safety Research. 2018;67:189-96. doi: 10.1016/j.jsr.2018.10.009. PubMed PMID: WOS:000455064700023.

46. Billot-Grasset A, Amoros E, Hours M. How cyclist behavior affects bicycle accident configurations? Transportation Research Part F-Traffic Psychology and Behaviour. 2016;41:261-76. doi: 10.1016/j.trf.2015.10.007. PubMed PMID: WOS:000382347300008. 